\title{
Prospect on Implementation of National Fish Logistics System: case in Indonesia
}

\author{
Muhamad Azhar ${ }^{1,2}$, Suhartoyo Suhartoyo ${ }^{1}$, Putut Suharso $^{3}$, Vivi Endar Herawati ${ }^{4}$, Nanik Trihastuti ${ }^{1}$

\begin{abstract}
${ }^{1}$ Faculty of Law, Diponegoro University, Prof. H. Soedarto SH street, Semarang 50275 Indonesia
${ }^{2}$ Center For Administrative Law Studies, Diponegoro University, Prof. H. Soedarto SH street, Semarang 50275 Indonesia

${ }^{3}$ Departement of Library Science, Diponegoro University, Prof. H. Soedarto SH street, Semarang 50275 Indonesia

${ }^{4}$ Department of Aquaculture, Faculty of Fisheries and Marine Science, Diponegoro University, Prof. H. Soedarto SH street,
\end{abstract} \\ Semarang 50275, Indonesia
}

\begin{abstract}
The policy to realize the sustainable supply of fish (especially marine fish commodities), face the fundamental constraints of seasonal factors, remoteness and characteristic of damaged fish commodities. At the time or harvest season, the production of catch fish can be abundant, but in the famine season, there is the opposite condition. Meanwhile, on the consumer (community) and industry side, fish supply must be available all the time without getting to know the season in constant amount. The research aims to find out the prospect of implementation of national fish logistic system or Sistem Logistik Ikan Nasional (SLIN), especially in Indonesia. This research is an empirical juridical research using statutory uproach approach, conceptual aproach, and comparative approach. Then analyzed using synthesis analysis. The results showed that SLIN implemetasi provide great benefits for national fish production, also directly contribute to the increase of national economic development. SLIN Management can run optimally if there is a synergy between all entities involved in each activity from upstream (production side) to downstream (consumption side). In the framework of looking at best practices for upstream downstream supply chain management of fishery commodities as well as in accordance with the mandate of Minister of Maritime Affairs and Fisheries No. 05/Permen-KP/2014 on SLIN. Thus, the Directorate General of Processing and Marketing of Fishery Products sees the importance of better implementation of SLIN. In the Initial Stage by providing several supporting facilities and involving the main operators and supporting operators in the management of selected locations.
\end{abstract}

Keywords: Policy Implementation; National Fish Logistics System (Sistem Logistik Ikan Nasional= SLIN)

Corresponding author: azharundip@gmail.com

This is also supported by the increasing consumption of fish from year to year with the rate of addition of $3-4 \%$ [6] thus indicating the availability of fish in the community has increased. On the other hand fish production, especially from sea catching, is still uncertain because it depends on the season so that the availability of fish both for fresh consumption and for raw materials can not be guaranteed throughout the year.

In relation to the aforementioned matters, one strategy that can be developed is to strengthen upstream downstream connectivity with a coordinated system and mechanism approach involving all relevant stakeholders. The system is a system capable of ensuring continuous availability of fish, both in harvests and famine, to consumers and raw materials processing industries. the system is expected to ensure the stability of fish prices at the market level, encourage the growth of the fishery 
industry, and maintain the quality of fish through quality assurance svstem.

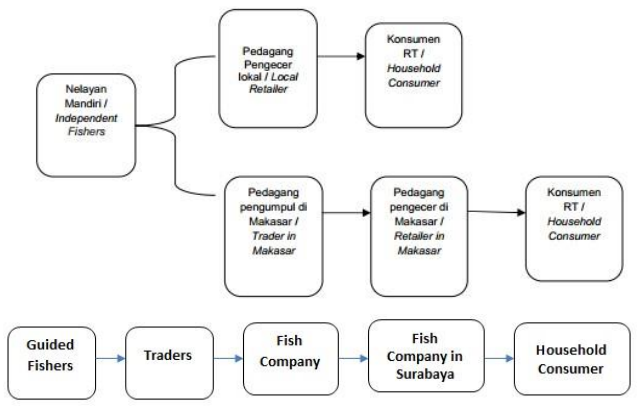

Fig. 1. Line marketing for fish catched in PPS Kendari in 2015 [6]

In addition, inefficient and long distribution channels and inadequate logistics infrastructure are also one of the problems in the provision of fish to meet consumption. The World Bank's publication on the 2010 Logistics Performance Index illustrates that Indonesia ranks 75 th out of 155 countries far below the Philippines (number 44) which is geographically similar to Indonesia [7]. It is often said that fisheries trading is the weakest in the chain of economic activity or in the flow of goods from the producer level to the consumer's hand [8]. So the adverse impact of logistics performance in Indonesia is less efficient is reflected in the high price of goods [2], [9] to be paid by consumers in addition to the disruption of competitiveness.

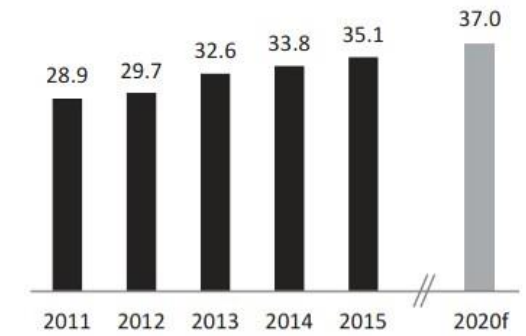

Source: OECD-FAO Agricultural Outlook

Fig. 2. Indonesia's fish consumption per capita ( $\mathrm{kg} /$ year)

Moving from these problems then the Directorate General of Marketing and Processing of Fishery Products sparked a national policy called SLIN. SLIN is an upstream-downstream supply chain management system for fish and its processed products that aims to stabilize the production of fisheries from upstream to downstream, price control and fulfillment of domestic consumption needs. SLIN must integrate all components from upstream (production/stock procurement), storage to distribution. It is hoped that with this policy the availability of fish can be guaranteed throughout the year and evenly distributed in all provinces in Indonesia but still not incriminating producers and consumers.

\section{ACTION PLAN OF NATIONAL FISH LOGISTIC SYSTEM}

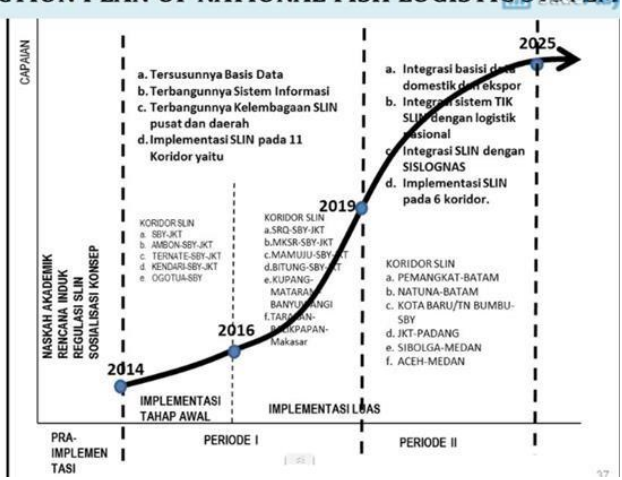

Management SLIN can run optimally if there is a synergy between all entities involved in each activity from upstream (production side) to downstream (consumption side). In the framework of looking at best practices for upstream downstream supply chain management of fishery commodities as well as in accordance with the mandate of Minister of Maritime Affairs and Fisheries No. 05/Permen-KP/2014 on SLIN. SLIN implementation of early stage is done in corridor of Kendari - Surabaya/Lamongan - Jakarta in order to fulfill requirement of raw material of pindang industry so it is expected to close the faucet of raw material import.

SLIN implementation has been done since 2014 and will run until 2025. Implementation of the early stages or period I dilukan in order to tersusunya database; establishment of information systems, establishment of central and regional SLIN institutions; and SLIN implemetasi on 11 corridors. While in the second period or the implementation phase is done in the framework of: Integration of domestic and export databases;

Integration of SLIN ICT systems with national logistics; Integration of SLIN with SISLOGNAS; and SLIN implemetasi on 6 corridors. Easily explanation of the steps can be seen in Figure 3. Thus, this study aims to identify and analyze the prospects for SLIN implementation and also to identify the constraints and challenges faced by the production sector in support of SLIN success.

\section{Research methods}

This research is a legal research looking from various perspectives. Law is seen as a space for the process of scientific study in order to seek truth. The use of relevant legal research wants to understand the law more thoroughly [10]. In performing implementation analysis, using the method of Regulatory Impact Assessment (RIA) [11], [12]. The need for RIA use arises from the fact that regulation generally has many impacts [13]. It is as difficult to predict without detailed study and consultation with affected parties. The economic approach to regulatory issues also emphasizes the high risk that regulatory costs can outweigh benefits.

Fig. 3. Action plan of national fish logistic system 


\section{Result and discussion}

The results of the study and discussion will focus on: First, determination of location and commodity SLIN initial implementation; Second, Determination of SLIN Implementation Operator Initial Stage, and Third is Provision of Supporting Facilities Infrastructure Utilization.

\subsection{Prospects for locating SLIN premises and commodities}

Initial SLIN implementation is carried out in corridors that are in real terms a production center and/or collecting center or source of catch fish, especially pelagic fish and connected with distribution centers or market centers to meet the needs of shade industry and other fishery industries

Determination of location of production center and/or collecting center and distribution center refers to Regulation of Minister of Marine and Fisheries RI number 05/PEMEN-KP/2014 about National Fish Logistic System, with criteria: a) Production center and/or collecting center with target as follows: Available ports for shipping or transshipment ports for fishing vessels; Adequate harbor infrastructure is available; Available port facilities, such as water, electricity and telecommunication facilities; and Available logistics services are held on a regular basis. b) the likelihood of distribution centers with functions as: distribution centers and interconnected with several districts / municipalities which become the main base of the shade industry; logistics services are available on a regular basis; accessible roads are available; there is a sufficient supply of electricity, water and telecommunications.

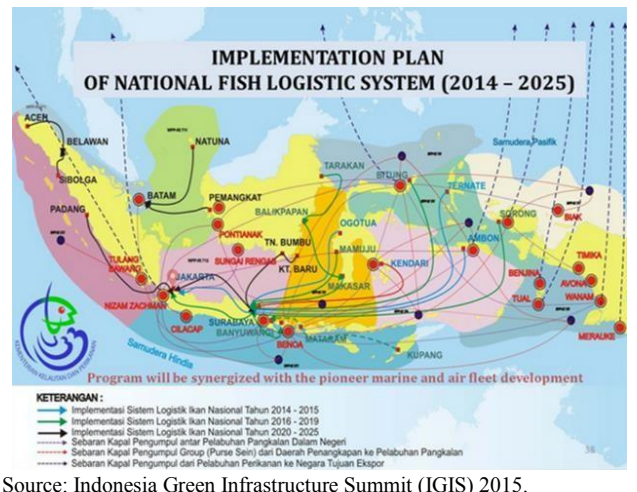

Fig. 4. Implementation Plan

In determining the corridor, consideration includes the potential and production of fisheries, commodity strategic values, local government commitments, regional development related studies and national policy support, such as MP3EI, SISLOGNAS, Fishery Industrialization, Minapolitan, Fishermen Lifestyle Improvement Program. Taking note of the aforementioned matters as well as for the effectiveness of the implementation, SLIN's initial implementation location is in the North Maluku - Sulawesi - Java - Bali corridor and involves business actors.

Fish commodities that become the object of management in SLIN implementation of this early stage is the type of pelagic fish especially for raw materials of industrial pengindangan and other fishery industries. As is known pindang fish is a processed fish that is widely consumed, especially in areas such as Java, Bali and West Nusa Tenggara. This also supported the existence of thousands of processing units of pindang fish spread in the region. Therefore, the provision of pelagic fish as raw material of pindang become very strategic to be managed.

Based on the above description it can be seen that the prospect of determining the location and commodity SLIN initial implementation is done seletif in certain areas that enable the purpose of SLIN utilization can be done optimally.

\subsection{Procedure of SLIN implementation of initial implementation SLIN}

Early SLIN implementation of SLIN Implementation is carried out openly and accountable and refers to the applicable regulations with the following activity description, Implementation of selection of candidate operator, administrative selection, competency test of operator candidate, and determination of candidate operator. At the stage of selection of prospective operators shall be made by the Selection Committee and Technical Team determined by the decision of the Director General which contains the Selection Committee and the technical team. The selection committee has a membership of at least 5 (five) people and mastered the technical aspects of SLIN and the administration of the management of state property originating from work unit representatives related to early SLIN implementation.

IMPLEMENTATION OF PHASE I (2014-2015) player SULAWESI TENGGARA - JAWA - BALI CORRIDOR

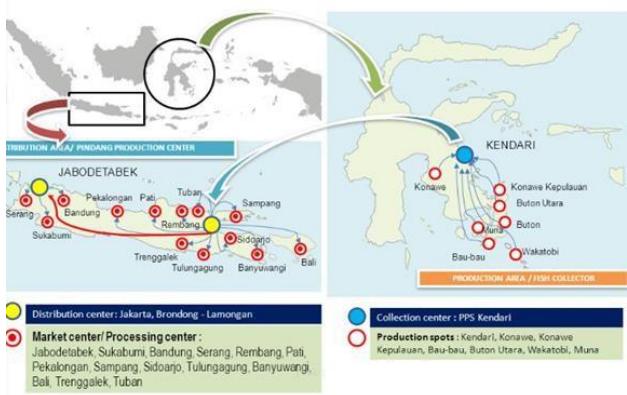

Source: Indonesia Green Infrastructure Summit (IGIS) 2015.

Fig. 6. Implementation of phase I

Administrative Selection is done by the Selection Committee on the things that the prospective operator must meet and the administrative selection method. 
Administrative prerequisites that must be fulfilled by the prospective operator, among others: Status of legal entity and permanent position of prospective operators; Organizational structure and stewardship of prospective operators; business experience in the field of fisheries; Financial and technical capabilities of prospective operators; and Operational Plan SLIN implementation activities of the initial stage of prospective operators. While the Administrative Selection Method is carried out with the following stages: 1) The selection committee invites at least 3 (three) prospective operators who are deemed able to complete the administrative requirements documents in the early SLIN implementation; 2) The selection committee shall assess the administrative completeness submitted by the prospective operator; 3 ) The results of the administrative completeness assessment by the selection committee shall be submitted to the Technical Team for further assessment; 4) The selection committee invites the candidate operator to present the SLIN implementation of Operational Activity Plan of early stage in front of the Technical Team for competency test.

While the stage of each step is competency test operator candidates conducted by inviting prospective operators who have submitted administrative completeness and declared passed by the selection committee to present the operational plan SLIN implementation activities early in front of the Technical Team. The result of the assessment of administrative completeness and suitability of the competency of the candidate operators conducted by the Selection Committee and Technical Team and declared to be passed, is shown to the Director General to be determined. Decision Letter of the Director General on Determination of Operator SLIN Implementation Initial Stage shall include the rights and obligations of the operator.

Operator rights in SLIN implementation are 1). Manage and coordinate the utilization of fishery product processing and marketing facilities provided by the government in the context of SLIN implementation in accordance with prevailing laws and regulations; 2) Propose additional infrastructure facilities in accordance with the duties and functions and availability of the budget required to optimize SLIN implementation; 3) Obtain technical guidance from the government in order to optimize SLIN implementation.

While operator liabilities are 1) Coordinate the involvement of all fishery business actors involved in the implementation of SLIN with the principles of fair and mutually reinforcing partnerships; 2) To accommodate all fisherman catches involved in initial SLIN implementation at a price disekapati the parties; 3) Ensure continuity and quality of availability of shade industry raw material requirements involved in initial SLIN implementation at a price agreed by the parties; 4) Provide maintenance and operational costs for the utilization of fishery product processing and marketing infrastructure; 5) Paying rent for utilization of fishery product processing and marketing facilities in accordance with applicable provisions; and 6) Create and submit quarterly, semiannual and annual reports to the Director General of Processing and Marketing of Fishery Products.
From the above description it can be seen under the preliminary implementation of SLIN implementation preliminary implementation allows can be done selectively and directed. This can be seen from the selection of selection committee selection to the right and obligation of SLIN operator candidates.

\subsection{Prospect of provision of utilization of supporting infrastructure}

The initial SLIN implementation was intended as a trial of the SLIN conception before being implemented in a more comprehensive concept in accordance with the general definition of SLIN regulated in Candidate of KP Number 05/Permen-KP/2014 on National Fish Logistics System. In connection with this, the Directorate General of Processing and Marketing of Fishery Products, since 2013 has provided several supporting facilities. In addition, the implementation of SLIN implementation in the established locations, also synergize with some infrastructure facilities that have been provided several years earlier. Several types of infrastructure facilities in the implementation of SLIN are as follows: First, marketing infrastructure facilities include Moving Marketing Facilities and other marketing infrastructure, and Second is the facilities of processing facilities such as ice factory, Cold Storage and ABF.

The utilization of infrastructure facilities supporting SLIN implementation of the initial stage by the operator in the framework of the implementation of the main tasks and functions whose status of assets is the property of the state must be leased as regulated in PP. 19 of 2006 on amendment to the government regulation no. 62 of 2002 on Tariff of Non-Tax State Revenue Applicable to the Ministry of Marine Affairs and Fisheries and Regulation of the Minister of Finance No. 96/PMK.06/2007 concerning Procedures for the Implementation, Use, Deletion and Transfer of BMN. The mechanism of rent of state property as such arrangement shall be stipulated as follows:

a. The lease term is adjusted to the Decree of Director General of Processing and Marketing of Fishery Products on the determination of initial SLIN implementation operator.

b. The lease agreement contract may be extended by mechanism and time of renewal in accordance with applicable regulations.

c. Requests for renewal of the lease term by the operator shall be submitted to the Goods Manager no later than 3 (three) months prior to the expiry of the rental period.

d. The goods manager will perform monitoring and evaluation on the implementation of the lease of state property facilities and infrastructure supporting the implementation of other early SLIN.

e. The amount of cold storage rental rate is calculated by using the formula: $\mathrm{T}=\mathrm{HD}+\mathrm{x}$ (where $\mathrm{T}$ is the rate of levied, HD is the base price set and $\mathrm{x}$ is the price adjustment factor).

f. The basic price tariff for Cold Storage services is Rp. 100 per $\mathrm{kg} /$ day. 
g. Terms of rental rates and other matters not regulated in PP. 19 of 2006 may refer to Regulation of the Minister of Finance Number 96 / PMK.06 / 2007 or other relevant regulations.

From the above description, the prospect of the provision of supporting infrastructure facilities related to the SLIN implementation is carried out by the Directorate General of Processing and Marketing of Fishery Products. Such support has been conducted since 2013 and has provided several supporting infrastructure facilities. In addition, the implementation of SLIN implementation in the established locations, also synergize with some infrastructure facilities that have been provided several years earlier. Several types of infrastructure facilities in the implementation of SLIN are as follows: First, marketing infrastructure facilities include Moving Marketing Facilities and other marketing infrastructure, and Second is the facilities of processing facilities such as ice factory, Cold Storage and ABF.

\subsection{Monitoring, evaluation and reporting}

Implementation of the national fish logistics system implementation also utilizes monitoring and evaluation monitoring procedures. This is done in order to detect early deviations that occur. A study conducted in 2015 by Rismutia Hayu Deswati and Muhadjir [6] that the results of the trials were seen by Kendari as upstream areas or suppliers of raw materials pindang still not able to supply full and sustainable. Kendari through KOMIRA as SLIN operator can only supply $65 \%$ of the total demand due to several causes including: the lack of ability and competence of fishermen in utilizing science and technology to support the arrest, the absence of government intervention in setting the price for fishermen and the difficulty of obtaining permits.

Implementation of Monitoring, Evaluation, and Reporting SLIN Monitoring is implemented with a view to taking into account the success of the SLIN program. Monitoring is carried out in the context of monitoring, guidance, and evaluation of utilization Initial SLIN implementation support infrastructure. Monitoring time can be carried out before, during, and after SLIN implementation in the early stages. While the implementation of Monitoring is done by the SLIN Implementation Technical Team of the early stage as well as assisting the experts both from internal ministries and external ministries.

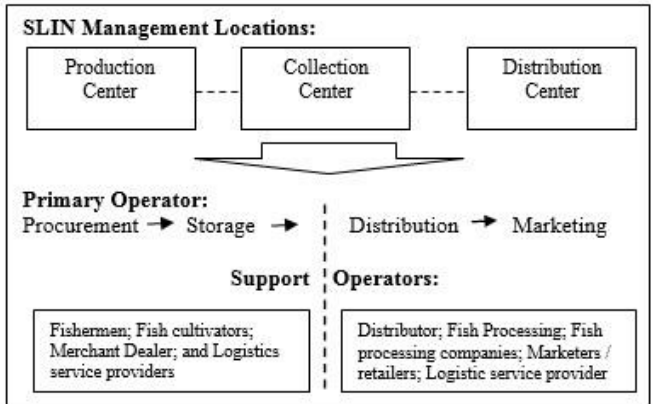

Fig. 7. Operationalization of SLIN management

Implementation Evaluation is done with a target on a particular object object. The evaluation object is emphasized on the suitability and effectiveness of the utilization of infrastructure facilities supporting SLIN implementation in the early stages by referring to the operator's obligations as well as the implementation objectives of early SLIN implementation, among others: 1). Increased percentage of uptake of fishermen products at initial SLIN implementation sites; 2). Control of prices across the supply chain at locations designated as early SLIN implementation areas; 3 ). The continuity of availability of shade industry materials at initial SLIN implementation sites, and 4). Availability of good quality industrial raw material.

In the final stages is the SLIN program reporting at the agency with the level of authority that exists. Reporting shall be conducted in two ways: first, the Operator is required to submit activity report to the Director General of Processing and Marketing of Fishery Products and forwarded to the relevant Provincial and Regency/City Maritime and Fishery Office, and Secondly, the SLIN implementation report of the initial stage is submitted in writing by the operator quarterly, semiannual and yearly. For operators who do not utilize the facilities or perform their functions in accordance with the obligations of operators which result in delayed implementation of initial SLIN implementation, may be subject to administrative sanctions in the form of revocation of appointment as operator.

From these descriptions it can be seen that Monitoring, evaluation, and reporting in order to know the advantages and kekuarangan program. However, there is also a lack of SLIN implementation. Lack of capability and competence of fishermen in utilizing science and technology to support the capture, the absence of government intervention in determining the price for fishermen and the difficulty of obtaining permits.

\section{Conclusion}

The prospect of SLIN (national fish logistics system) implementatation has shown a positive trend. the implemetation of SLIN provides substantial benefits to national fish production, directly contributing to the increase of national economic development. SLIN Management can run optimally if there is a synergy between all entities involved in each activity from upstream (production side) to downstream (consumption side). In the framework of looking at best practices for upstream downstream supply chain management of fishery commodities as well as in accordance with the mandate of Minister of Maritime Affairs and Fisheries No. 05/Permen-KP/2014 on SLIN. Thus, the Directorate General of Processing and Marketing of Fishery Products sees the importance of better implementation of SLIN. In the Initial Stage by providing several supporting facilities and involving the main operators and supporting operators in the management of selected locations. Determination of location and commodity SLIN initial implementation is done seletif in certain area of area that 
enables purpose of SLIN utilization can be done optimally. But there is also a lack of SLIN implementation. Lack of capability and competence of fishermen in utilizing science and technology to support the arrest, there is no government intervention in determining the price for fishermen.

\section{Acknowleddments}

The first author would like to thanks to the Dean of Law Faculty (Prof. Dr. Retno Saraswati, S.H., M.Hum), Diponegoro University for his support and kindness.

\section{References}

1. M. Nielsen, P. Andersen, L. Ravensbeck, F. Laugesen, D. M. Kristófersson, and H. Ellefsen, "Fisheries management and the value chain: The Northeast Atlantic pelagic fisheries case," Fish. Res., vol. 186, pp. 36-47, 2017.

2. R. M. Rosales et al., "Value chain analysis and small-scale fisheries management," Mar. Policy, vol. 83, no. May, pp. 11-21, 2017.

3. F. Jensen, H. Frost, and J. Abildtrup, "Fisheries regulation: A survey of the literature on uncertainty, compliance behavior and asymmetric information," Mar. Policy, vol. 81, no. March, pp. 167-178, 2017.

4. Marsetio, "Indonesian Sea Power and Regional Maritime Security Challenges," J. Marit. Stud. Natl. Integr., vol. 1, no. 1, pp. 34-46, 2017.

5. I. N. Putra A., A. Hakim, S. H. Pramono, and A. S. Leksono, "The effect of strategic environment change toward Indonesia maritime security: Threat and opportunity," Int. J. Appl. Eng. Res., vol. 12, no. 16, pp. 6037-6044, 2017.

6. R. H. Deswati and M. Muhadjir, "Support of Production Aspect in National Fish Logistics System (SLIN) in the Kendari City, Southeast Sulawesi (Dukungan aspek produksi dalam sistem logistik ikan nasional (SLIN) di Kota Kendari, Sulawesi Tenggara)," J. Sos. Ekon. Kelaut. dan Perikan., vol. 10, no. 2, pp. 191-202, 2016.

7. B. Hoekman et al., Connecting to compete 2010: trade logistics in the global economy - the logistics performance index and its indicators. Washington DC: World Bank, 2010.

8. S. W. Purcell, B. I. Crona, W. Lalavanua, and H. Eriksson, "Distribution of economic returns in small-scale fisheries for international markets: A value-chain analysis," Mar. Policy, vol. 86, no. June, pp. 9-16, 2017.

9. M. Laraswati, A. D. Guritno, N. E. Kristanti, and E. Suwondo, "Analysis of logistics cost structure of fish cold supply chain in Java Island," AIP Conf. Proc., vol. 1755, 2016.
10. S. Halliday and P. Schmidt, Conducting Law and Society Research: Reflections on Methods and Practices. New York: Cambrige University Press, 2009.

11. A. C. M. Meuwese and S. van Voorst, "Regulatory impact assessment in legal studies," in Handbook of Regulatory Impact Assessment, C. A. Dunlop and C. M. Radaelli, Eds. Cheltenham: Edward Elgar, 2016, pp. 21-32.

12. C. Kirkpatrick, D. Parker, and Y.-F. Zhang, "Regulatory Impact Assessment in Developing and Transition Economies: A Survey of Current Practice," Public Money Manag., vol. 24, no. 5, pp. 291-296, 2004. 13. V. Jakupec and M. Kelly, "Development aid: Regulatory Impact Assessment and conditionality," Impact Assess. Proj. Apprais., vol. 34, no. 4, pp. 319-329, 2016. 